\title{
熱環境からみた冬期の居住性能に関する地域特性の変化
}

一東北地方都市部を対象とした 10 年前の調査との比較一

\section{CHANGE IN REGIONAL CHARACTERISTICS OF WINTER THERMAL PERFORMANCE AND OCCUPANT'S BEHAVIOR OF DETACHED HOUSES \\ IN TOHOKU CITY AREA FOR 10 YEARS}

\author{
吉野 博*, 長谷川 兼一** \\ Hiroshi YOSHINO and Ken-ichi HASEGAWA
}

\begin{abstract}
The thermal performance and occupant's behavior of about 1000 detached houses in Tohoku city area and in Sapporo and Futyuu as references were investigated in winter of 1992 by means of questionnaire and liquidcrystal thermometers. Since the same investigation have been conducted in winter of 1982 , the change during 10 years in such thermal performance and occupant's behavior of houses was analyzed. The results are shown as follows:

1. It was found that cities of Tohoku area could be divided into 4 groups from the viewpoint of thermal performance and occupant's behavior. Aomori was similar to Sapporo, and these of Tohoku city area become more and more like Sapporo during 10 years.
\end{abstract}

2. In 10 years ago there were a little difference in performance level of thermal insulation and air-tightness between Tohoku city areas. But the performance of thermal insulation and air-tightness in Aomori and Morioka was improved during 10 years, and it was similar to Sapporo.

3. Average air temperatures in living room and bed room of all houses during heating time after supper were $19.6 \%$ and $12.8 \mathrm{C}$, respectively. Average living room is $1.5 \sim 3 \mathrm{C}$ higher than in 10 years ago.

Keywords: Detached houses, Thermal environment, Questionnaire survey, Room temperature, Multi-variate analysis 戸建住宅，熱環境，アンケート調査，室温，数量化分析

\section{1.はじめに}

1982年2月に筆者ら注東北地方都市部を中心とした約 1000 戸の住 宅を対象として,熱噮境からみた冬期の居住性能に関するアンケート 調査と液晶温度計を用いた室温調査を実施した。その結果, 東北地方 12 都市の居住性能註，i)比較的札幌に近い青森，秋田，ii)札幌と汶対 照的であり，府中と同グループと見なせる宮古，福島，いわき，iii) そ れらの中間に位置し両者にまたがる八戸，盛岡，横手，山形，酒田， 仙台，会津若松の3つのグループに分類できることを明らかにし，居 間室温の特性や団らル時の室温に及ぼす因子, 石油消費量に及ぼす因 子の影響度についても含めて既に報告した 1。その後，東北地方の住 宅に扔ける断熱材の普及率は上昇し注1, 暖房用エネルギ一消費量も増 大した。従って, 室温などの居住環境も大きく変化したものと推察さ れる。そこで，10 年後の1992 年 2 月に同様の方法で，同じ都市を対 象としてアンケート調查と室温調査を実施した。そひ結果，10年間で 興味深い変化が見られたので報告寸る。な㧍, 室温に関しては新たに 㾛室についても調心゙ている。

\section{2. 調査概要}

\section{1 対象都市之調査期間}

表 1 に対象都市，期間，回収状況，調査期間中ひ外気温並びに 10 年
表 1 調查都市と対象住戸数，調查期間，調查期間中の外気温

\begin{tabular}{|c|c|c|c|c|c|c|}
\hline \multirow{2}{*}{ 対象都市 } & \multirow{2}{*}{ 調查期間 } & \multirow{2}{*}{ 配布数 } & \multirow{2}{*}{ 回收数 } & \multirow{2}{*}{ 使用デ゙ } & \multicolumn{2}{|c|}{ 調查期間中心外気淐 } \\
\hline & & & & & 1992年 & 1982年 \\
\hline 札幌市 & $2 / 20 \sim 27$ & 80 & 68 & 54 & $-2.6^{\circ} \mathrm{C}$ & $-3.8^{\circ} \mathrm{C}$ \\
\hline 青森市 & $2 / 15 \sim 26$ & 80 & 74 & 52 & $-0.8{ }^{\circ} \mathrm{C}$ & $-3.4^{\circ} \mathrm{C}$ \\
\hline 八戸市 & $2 / 14 \sim 24$ & 80 & 78 & 64 & $0.6^{\circ} \mathrm{C}$ & $-3.4^{\circ} \mathrm{C}$ \\
\hline 盛岡市 & $2 / 14 \sim 24$ & 80 & 74 & 52 & $-1.6^{\circ} \mathrm{C}$ & $-0.3{ }^{\circ} \mathrm{C}$ \\
\hline 宮古市 & $2 / 15 \sim 24$ & 74 & 74 & 59 & $0.8^{\circ} \mathrm{C}$ & $0.2{ }^{\circ} \mathrm{C}$ \\
\hline 秋田市 & $2 / 14 \sim 24$ & 66 & 65 & 54 & $0.0^{\circ \mathrm{C}}$ & $0.0^{\circ} \mathrm{C}$ \\
\hline 横手市 & $2 / 15 \sim 27$ & 102 & 87 & 81 & $-1.1^{\circ} \mathrm{C}$ & $-1.5{ }^{\circ} \mathrm{C}$ \\
\hline 山形市 & $2 / 15 \sim 24$ & 58 & 58 & 47 & $-0.2^{\circ} \mathrm{C}$ & $1.2^{\circ} \mathrm{C}$ \\
\hline 酒田市 & $2 / 15 \sim 24$ & 80 & 80 & 68 & $1.0{ }^{\circ} \mathrm{C}$ & $-0.6^{\circ} \mathrm{C}$ \\
\hline 仙台市 & $2 / 16 \sim 24$ & 232 & 210 & 148 & $1.5{ }^{\circ} \mathrm{C}$ & $2.1^{\circ} \mathrm{C}$ \\
\hline 福島市 & $2 / 16 \sim 3 / 9$ & 237 & 217 & 158 & $3.0^{\circ} \mathrm{C}$ & $-0.2^{\circ} \mathrm{C}$ \\
\hline 会津若松市 & $2 / 14 \sim 26$ & 76 & 74 & 60 & $-0.9{ }^{\circ} \mathrm{C}$ & $-1.0^{\circ} \mathrm{C}$ \\
\hline いわき市 & $2 / 16 \sim 24$ & 81 & 69 & 55 & $3.8 \mathrm{C}^{\circ} \mathrm{C}$ & $3.8^{\circ} \mathrm{C}$ \\
\hline 府中市 & $2 / 16 \sim 24$ & 44 & 40 & 18 & $6.2{ }^{\circ} \mathrm{C}$ & $3.8^{\circ} \mathrm{C}$ \\
\hline
\end{tabular}

前の調查期間の外気温を示寸。対象都市は, 10 年前の調査と同様であ り，東北地方 12 都市と札幌，府中である。室温し調査期間汴，1992 年2月の連続した一週間である。外気温は各都市の最寄りひ気象観測 データを用いた。

\section{2 調查方法と内容}

原則として各都市り小学校2校を旧市街地と新興住宅地から各都市 の教育委員会からの紹介により選定した。但し，都合により札幌市に
* 東北大学大学院工学研究科都市・建築学尃攻 教授・ 工博

** 信州大学_工学部社会開発工学科 助手 ·博士 (工学)
Prof., Dept. of Architecture, Urban Planning and Building Eng., Graduate School of Eng., Tohoku Univ., Dr. Eng.

Research Assoc., Dept. of Architecture and Civil Eng., Faculty of Eng., Shinshu Univ., Dr. Eng. 
ついては, 札幌市衛生局の職員の住宅を対象に選んだ。青森の1校は 中学校である。仙台と福島で沬都市内の地域性学調べる目的で小学校 6 校を選儿だために調査数が多く, 府中は 1 校のみであるために逆に 少ない。5 年生 1 クラスの児童を通して，アンケート調査用紙と液晶 温度計注2を配布し, 調查用紙への記入, 居住者による居間温度の読み 取りを依頼し，調査終了後学校ごとに回収をお願いした。

対象住宅には集合住宅も含まれているが, 地域比較のために除外し， 表 1 の70戸を分析のために用いた。また, 後半の数量化分析の対象 住戸注アンケートの回答に欠測のない合計 380 戸である。

室温の測定注前回と同様に, 液晶温度計を床上 $1 \mathrm{~m} \circlearrowleft$ 柱や壁に貼り 付けてもらい, 起床時(以後, 朝と呼ぶ), 日中(昼), 夕食後の団的 儿時(夜)の1日3回，1週間にわたって温度計の読み取りを依頼した。 また, 今回汸, 各住戸に2枚配布し居間と主度室における温度を測定 した。アンケート調査内容は表2 に示す通りである。

\section{3. 調査結果と 10 年前との比较}

\section{1 温熱環境に関するアンケート調査結果}

アンケート調查の主な結果を度数分布で図 1 に示す。

(1)居住者の特性 家族数は各都市とも 4 5人が最も多く, 全平均は 4.6 人である。各都市の年間収入の平均值泣 550 万 650 万円程度であ る。世带主の年齢牥 40 代が $60 \sim 70 \%$ を占めており，職業は会社勤務 が圧倒的に多いが八戸と宮古で注自営がやや多い。全体的に居住者の 特性に地域的な差があまり見られないの泣，前回ひ調查と同様である。

(2)建物構造の特徵 在来構法に上る木造が全体の $85 \%$ を占め, RC 造が若干多くなっている。築 10 年以内の住宅计全体の約 $40 \%$ を占め て抢り，特に盛岡では $64 \%$ になっている。逆に，築 20 年以上の古い 住宅忟，酒田，福島で30\%前後を占め，全体で洨 $20 \%$ である。各都 市とも築年数には汇らつきが見られる。全体の床面積の平均值は前回 上り $13 \mathrm{~m}^{2}$ 増加して扰り $121.0 \mathrm{~m}^{2}$ である。

（3）建物の断熱気密性能断熱材の使用率は各都市とも前回上り 5 30\% 上昇しており，札幌で沬 $100 \%$ に達している。全体の使用率は 64\%である。使用部位仗外壁が最も多く，続いて天井，床である。外 壁, 天井両方使用している住戸山かなり多いが, 床も含めて全てとい う住戸はどの地域も $10 \%$ 未満である。居間の空構成仗, 札幌, 青森, 八戸，盛岡，秋田で 2 重の住戸が多い。その他の都市は，アルミサッ シ1枚，あるい仗空と障子がほとルどである。府中ではアルミサッシ 1 枚が $70 \%$ 程度である。居間の床構成は, 札幌, 秋田, 盛岡で板敷き が最も多く，その他の都市では畳あるい性畳と絨掞が多くなっている。 雨戸の使用率汢南下寸るるぼ高いが, 全体的に前回上り小さくなって いる。居間の日当たり汁全体の $65 \%$ の住宅が良いと答えている。居間 のまきま風の感じ方㳉各地域とも，ほとんど感じない，少しだけ感じ るといら答えが多く，全体の $70 \%$ 以上を占めている。前回の $60 \%$ 上 りも小さくなっているといえる。

(4)居間の使用暖房設備 札幌, 青森では煙突付石油ストーブが多 く, 他ひ都市では $\mathrm{FF}$ 式石油温風暖房機, 石油ファンヒータ, 電気ご たつり使用が多くなっている。セントラルヒーティングの使用が札幌 で多いひは前回と同じである。暖房時間恃, 札幌, 青森, 横手, 秋田, 酒田で法終日もしくは起床時から就寝時が注とんどであり，特に札幌 で汶終日暖房が約 $50 \%$ 老占めている。全体的に暖房時間は, 前回上り 増加している。

(5)各種住宅設備の保有状況 暖房器具以外の住宅設備では, 冷房設

\begin{tabular}{|c|c|}
\hline 温熱環境 & 朝, 昼, 夜における居間及び箒室の室温 \\
\hline 設備 & 使用暖房器具, 保有住宅設備 \\
\hline 住まい方 & $\begin{array}{l}\text { 暖房時間, 暖房期間, 着衣量, 結露対策, } \\
\text { 洗濯物を干寸場所, 空気污染の対策 }\end{array}$ \\
\hline シェルター性能 & $\begin{array}{l}\text { 建設時期, 床面積, 構造, 断熱材, 雨戸・空・床 } \\
\text { の構成, 日当たり, 結露状況, すき方 }\end{array}$ \\
\hline エネルギー消費量 & 1月，冬期の石油消費量 \\
\hline 居住者特性 ； & 家族構成；年齢，年間収入，職業 \\
\hline
\end{tabular}

備, 除湿器, 布団乾燥機, 洗濯物乾燥機に地域的な差がみられる。冷 房設備牥南下寸るにつれ保有率牥高くなり, 府中で $90 \%$, 福島で $65 \%$ となっている。また, 除湿器仗秋田, 横手, 酒田で多く, 布団乾燥機 は東北地方北部で保有率が高く $60 \sim 85 \%$, 洗濯物乾燥機㴗島や府中 で高い。これらの設備の保有率注前回と比べて5 40\%上昇している。 また，居室換気搦の保有率も前回上り全体で $15 \%$ 増加している。

(6)団らん時の着衣量 団ら儿時の着衣量には，地域的な差は見られ ないものの, 女性の方が全体的に薄着であり, 前回より0.1clo程度薄 着になっている。

(7)居間の結露 居間の結露注泣全体の $72 \%$ の住宅で「あり」と答え て打り, 前回上り $26 \%$ 増加している。これ注, 住宅のシェルター性能 が向上しているにも関わらず, 開放型石油ストーブが使用されている ことが原因の一つと考えられる。札幌で注「あり」の住宅が最も少な く約 $60 \%$, 逆に仙台で最も”多く約 $80 \%$ となっている。結露する部位 については, 各都市とも空が大部分を占め, その他の部位ではほとル ど見られない。結露の対策については換気と断熱に気を付けていると 答えた住宅が多いが，地域的な差忙見られない。また，何もしないと 答えた住宅が全体の約 $52 \%$ であり, 前回上り $10 \%$ 汪ど減少している。 (8)石油消費量 調查した石油消費量には, 暖房以外に風呂や給湯に 用いられる消費量も含まれている洼。1992年1月打上び平年の冬期に 使用される量注5について調査した。札幌ひ1月分の平均消費量が 304 リットル，冬期消費量は 1700 リットルであり，秋田ひ1.5倍, 府中ひ 4.6 倍である。全住戸の平均は 1 月分が 201 リットル, 冬期が985リッ トルである。

図2に各都市に扔ける住宅の一世帯当たりの冬期石油消費量を前回 の調査結果とあわせて示守。前回の全住戸の平均は872リットルであ り，113リットル増加している。図を見ると，ほとんどの都市に扔い て増加しているが，札幌では 1720 リットルに減少しており，二れは 断熱気密化が進んでいるためと推察される。

\section{2 各都市における室温の調査結果}

図引に各都市に扎ける居間及び寝室温度の平均値士標準偏差, 最大・

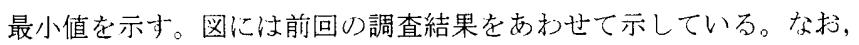
各住戸の室温として1週間の平均值を用いた。

居間温度ひ全体の平均值朝 $13.9 \mathrm{C}$ ，昼 $17.9 \mathrm{C}$ ，夜 $19.6 \mathrm{C}$ である。 前回忙, 朝 $10.2 \mathrm{C}$, 昼 $16.5 \mathrm{C}$, 夜 $17.9 \mathrm{C}$ であり平均值は $1.4 \sim 3.7 \mathrm{C}$ 上 昇して打り，特に朝ひ室温上昇が大きい。また，標準偏差け前回上り も若干小さい。どあ都市に执いても朝, 昼, 夜の順に平均值は高くな り，いわきを除いて標準偏差注小さくなっている。朝り標準偏差が大 きい理由は暖房寸る住戸としていない住戸が混在しているためと考え られる。前回と同様に, 札幌, 青森, 秋田心居間室温泣朝, 昼, 夜を 通じて高めである。逆に，福島，いわき泜くなっている。

寝室温度ひ全体ひ平均值は朝 $9.0 \mathrm{C}$, 昼が $12.6 \mathrm{C}$, 夜 $12.8 \mathrm{C}$ であり, 居間温度上りも4.9 6.8 C低い。札幌，仙台，いわきを除いて朝，昼， 


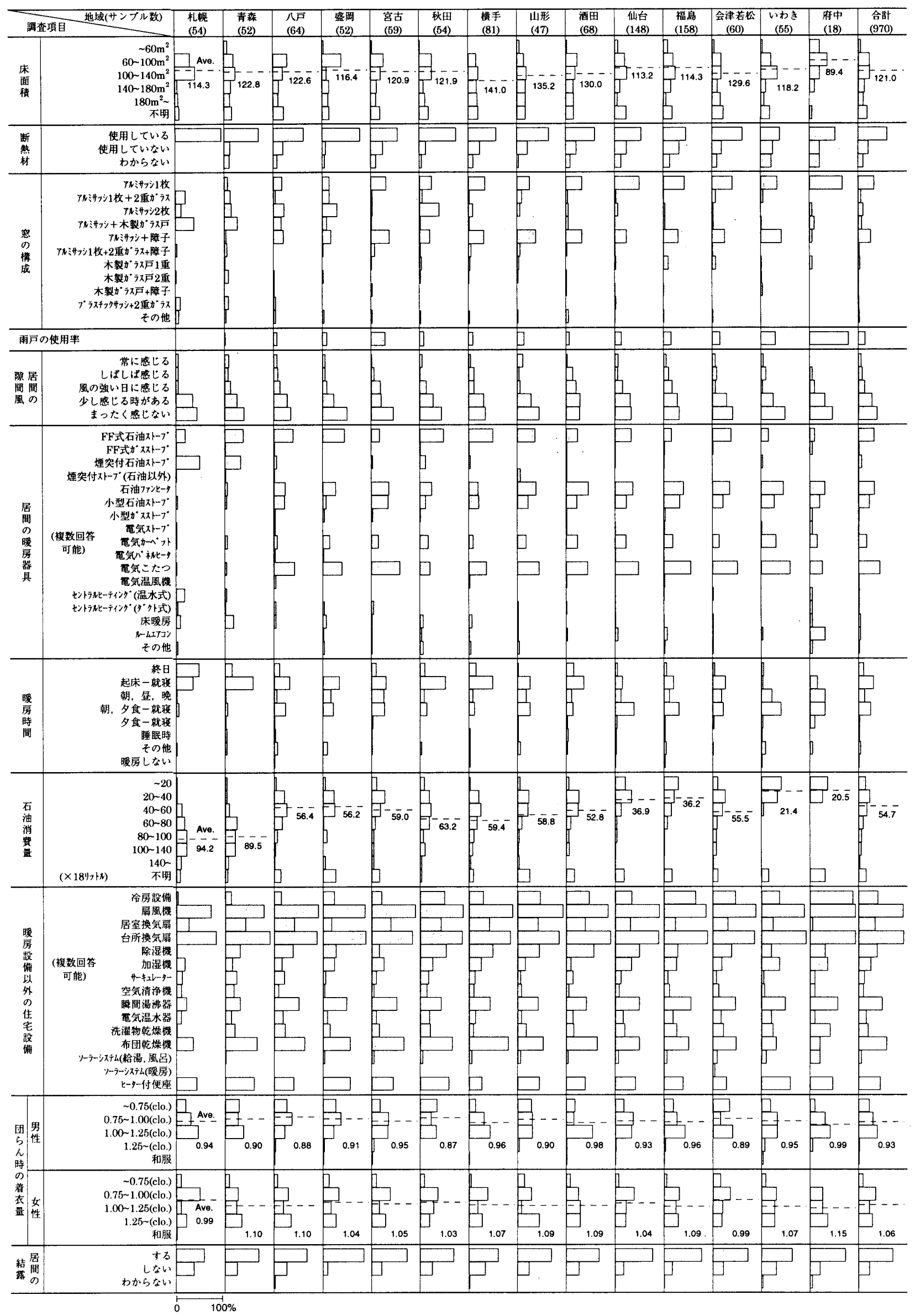

図 1 アンケート調查結果の度数分布 


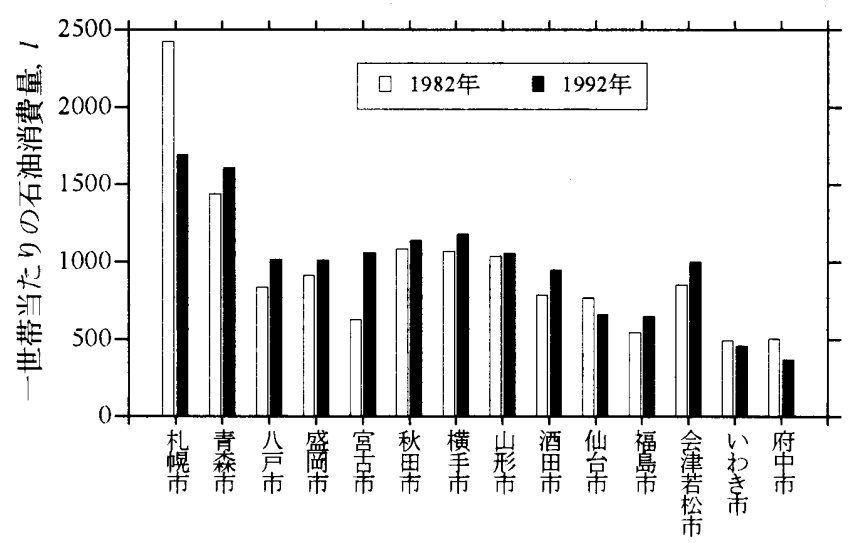

図2 1 世帯当たりの石油消費量

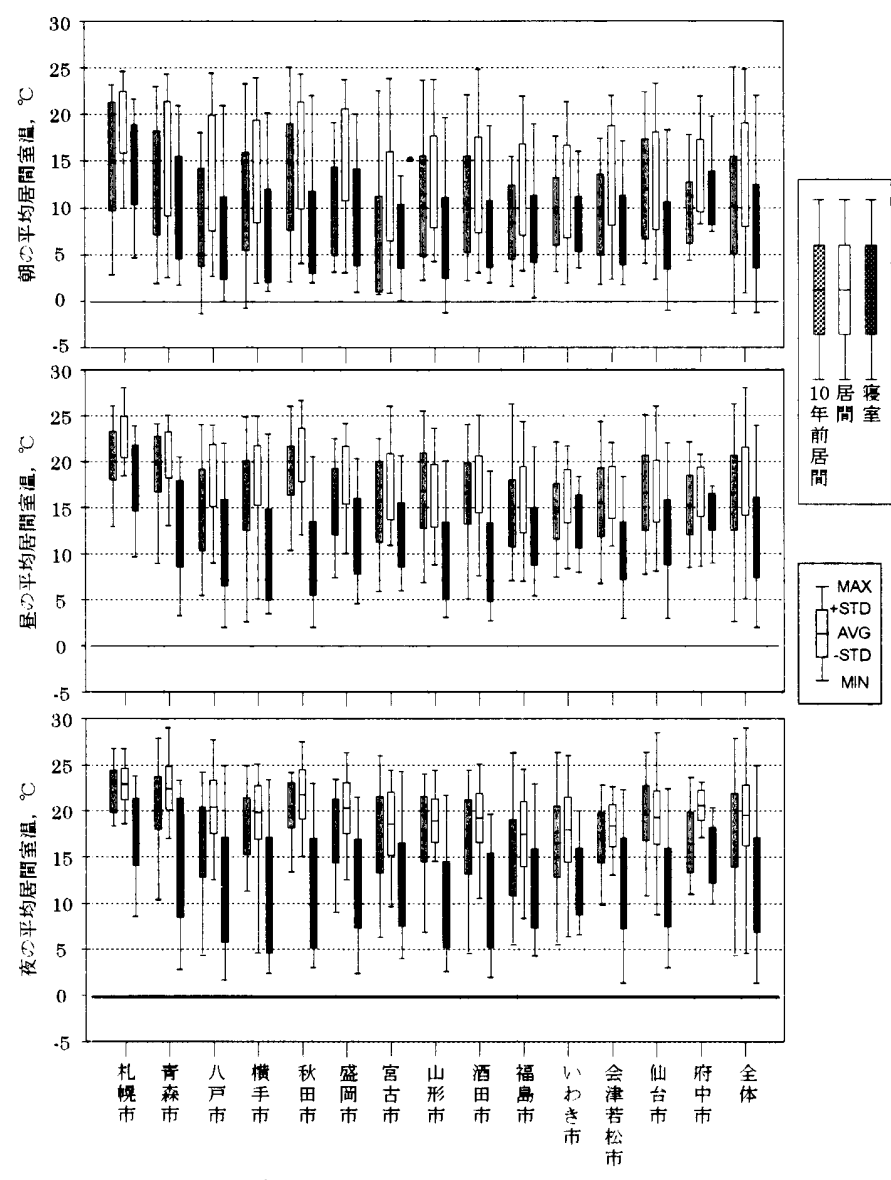

図 3 各都市の室温の平均值, 標隻偏差, 最大 · 最小值

夜の順に平均值が高くなる。また，標準偏差はどの都市も昼が最も小 さい。これは昼に暖房していない住戸が多く，朝，夜に注暖房する住 宅としない住宅が混在しているためと考えられる。札幌, 府中, 青森 で㳉, 朝, 昼, 夜とも寝室室温が高く, 山形, 横手, 酒田では低い。 各都市の居間と葠室の温度差の平均值は札幌が最も小さく,夜の温度 差は5.1Cであった。しかし，秋田では $10.7 \mathrm{C} と$ 最も大きく，室間ひ 温度差が未だに大きい住宅が多いことがわかる。

\section{4. 数量化理育を用いた居住性能に関する分析}

\section{1 団らん時の室温に及ぼす因子の影要度}

10年間の室温上昇に及ぼした因子を把握するために, 数量化理論 I 類注6による分析を行った。目的変数汁夜の居間室温であり, 説明変数 として室温と関連が深いと考えられる18因子を選しだ。結果を図4に 示寸。
重相関係数は 0.68 , 奇与率流 0.46 である生 7 。室温への寄与が大き い因子は都市, 床面積, 暖房時間タイプ, 石油消費量, 年間収入など である。逆に, 住宅構造, 床の構成, 断熱材の有無, 日照, 雨戸の有 無は室温に対寸る寄与が小さい。室温に対する寄与が大きい因子にの いて見ると以下の通りである。(1)都市では，札幌，青森，秋田，府中 のウェイトが高く, 宮古, 山形, 福島, 会津若松が低い。ウェイトの 最大差汒3.6Cであり前回忙4.7Cであったことから，都市間でひ室温 の差が小さくなったことがわかる。(2)床面積について㤌，面積い增加 に伴ってウェイトが低くなり，“60 $\mathrm{m}^{2}$ 未満”の住戸と“ $180 \mathrm{~m}^{2}$ 以上” の住戸で注2.5Cの差がある。(3)暖房時間タイプについては，暖房時 間の增大にともないウェイトが高くなる傾向が見られ，“終日暖房”之 “夜のみ暖房”とのウェイト差㳉2.6 Cである。(4)石油消費量㳉, 20 100(×18 リットル)の間で㳉消費量り増加に伴いウェイトが高く なる傾向が見られる。(5)着衣量について㳉男性ひ場合, clo 值ひ増加 に伴ってウェイトは低くなり“0.75 clo 以下”と“1.25clo以上”では $2.5 \mathrm{CW}$ 差がある。一方，女性の場合は男性の場合ほど大きな差泣見门 れないが同様の傾向を示し，“0.75 1.00clo”と“1.25clo以上”とひ 間で $0.9 \mathrm{C}$ 差がある。(6)年間収入の場合は “400万円以下”で室温が 低く，それ以外で恃大きな差汢見られない。

因子の中では，前回の結果と同様に都市に上る寄与が最も大きい。 都市のウェイトの差注,シェルター性能や暖房形態以外に自然環境や 社会環境などの相違にも対応寸゙万と考え，自然環境として暖房度日を， 社会環境として都市別民力総合指数引を代表少る因子として，各都市 ひウェイトとけ相関係数を求めると，い杂れも０.3 程度であり，さら に，二つの因子に上る重相関係数㳉 0.4 であった。上って，都市のウェ イトひ差をこれらひ因子にて説明することは不十分であり，さらに検 討が必要といえる。

\section{2 石油消費量に及ぽす因子の影要度}

目的変数を冬期ひ石油灯油消費量, 説明変数として石油消費量と関 連が深いと思和れる23 因子を選儿で数量化理論 I 類に上る分析を 行った。結果を図5に示寸。

重相関係数は 0.72 , 寄与率沬 0.52 である注8。石油消費量に強く影 響を与える因子は都市, 主暖房器具, 室温, 暖房期間, 石油暖房器具 使用の部屋数, 年間収入である。逆に影響の小さい因子注住宅構造, 空構成, 床構成, 日照, 雨戸の有無, こたつの有無などである。石油 消費量八の奇与が大きい因子について見ると以下ひ通りである。(1)都 市の中では札幌, 青森のウェイトが高い。道にウェイトが低いの流, いわき, 府中である。カテゴリーウェイトの最大差は44缶(1缶18リッ トル)である。(2)主暖房器具については“セントラルヒーティング”の 使用住戸が平均值に対して7.8年多い。それ以外仗平均值上りも，低く， “セントラルヒーティング”と“開放式ストーブ”との差は 13.4 午で ある。(3)朝ひ室温については, どひカテゴリーウェイトもマイイスに なっている。夜についてい, 室温が高いはどウェイトが高くなる傾向 が見られる。(4)暖房期間は “7ヶ月以上”ひウェイトが 15.3 缶と大き く，その他のカテゴリー注マイナスのウェイト在示与。カガゴリー ウェイトの最大差は21.1缶である。(5)石油暖房器具使用ひ部屋数认, 部屋数が多い汪どウェイトが高くなる。使用部屋数が“ 1 室”之“ 4 室 以上”では 12.5 缶の差が見られる。(6)年間収入汒“1000万円以上” ウェイトが他のカテゴリー上り大きく,その他りカテゴリーのウェイ トの差梳小さ2 2.7 午である。

以上の因子の中で泣, 前回ひ結果と同様に都市に上る奇与が最も大 


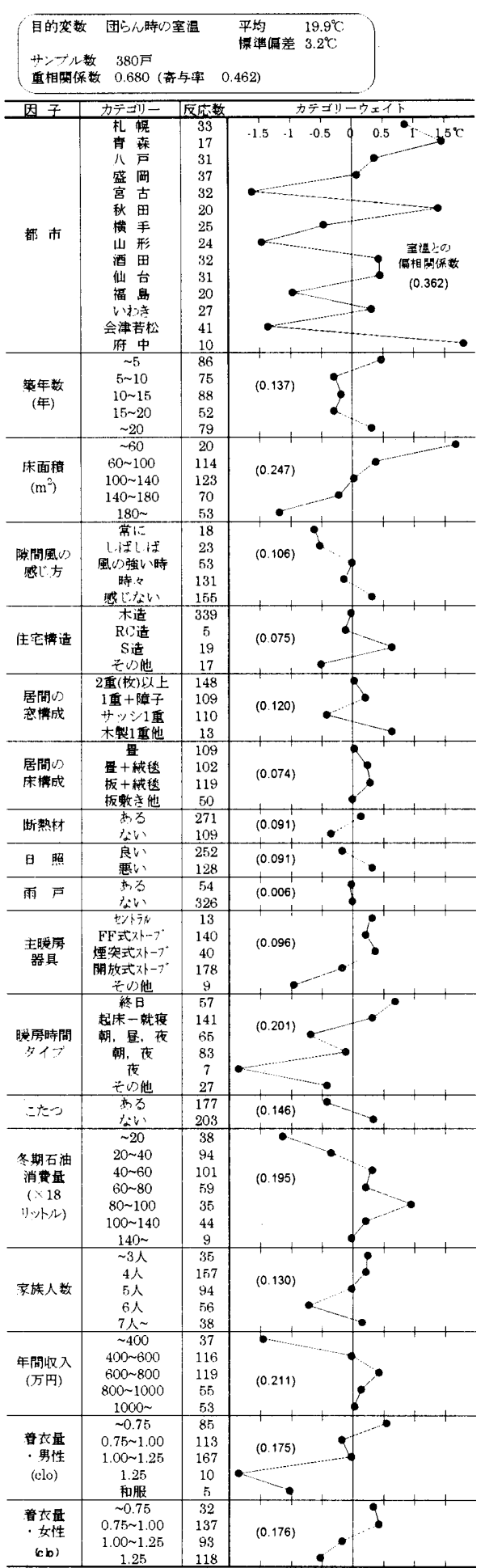

図4 団らん時の室温の数量化 I 類による分析結果

きく,札幌で消費量が多いのは, 外気温が低いこ とや暖房面積が広いことなどが考えられる。ま た，昼と夜い室温ひ影響が前回と比べて大きく なっている。

\section{3 冬期の居住性能に関する地域特性の分析}

居住性能に関する地域特性を総合的に明らか にするために数量化理論 III 類注 9 による分析を 行へた。使用した因子及びカテゴリーは表引に示 ず 19 因子 86 カテジリーである。
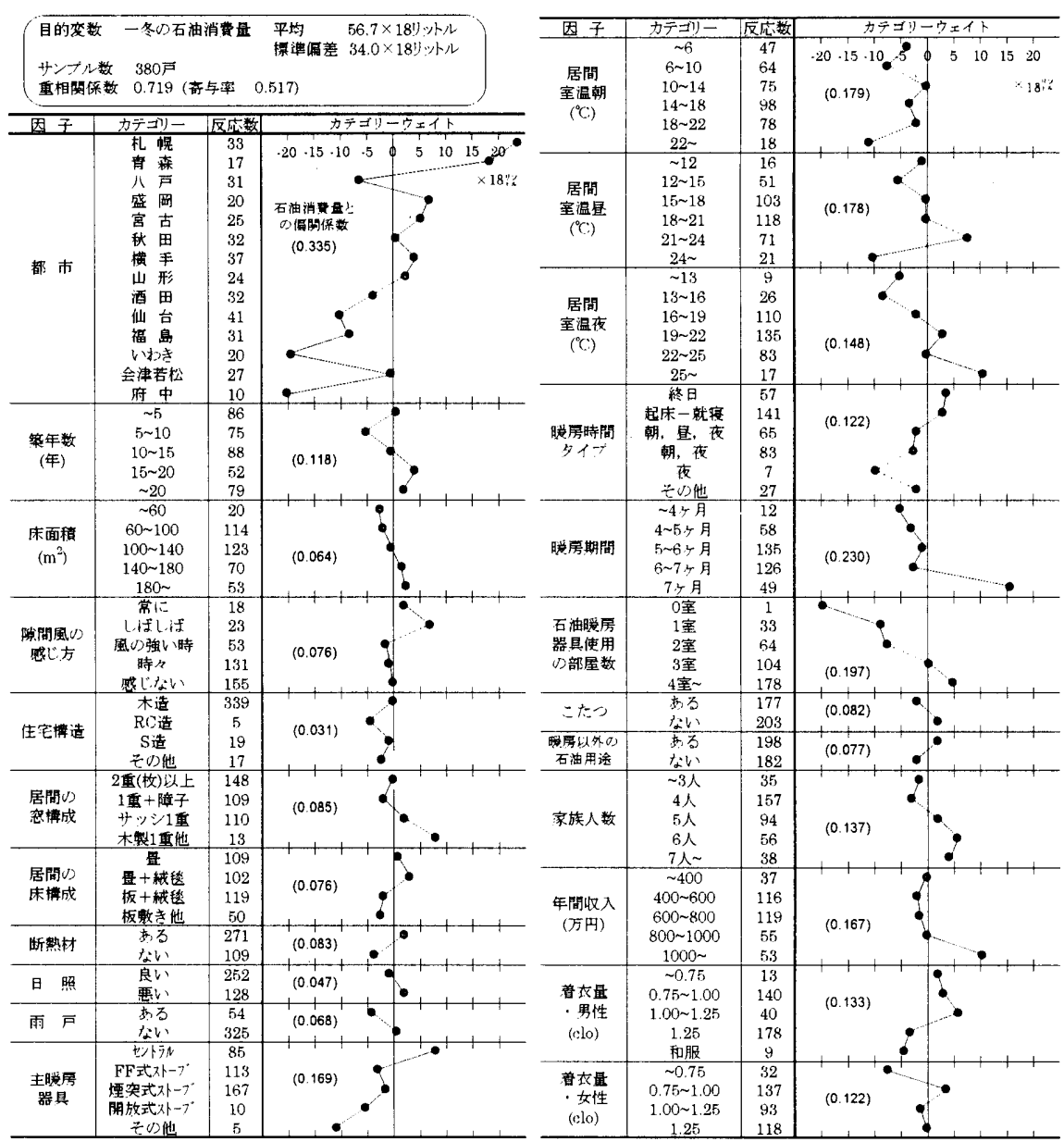

図 5 冬期の石油消費量の数量化 I 類に上る分析結果

（1)シェルター性能に関する因子を用いた分析 表引の1 8の因子を用いて分析を行った。 計算結果から相関係数の高い順に得られた I 軸, I軸に関するカテゴリーの散布図を図6(a) に，各都市ごとの住戸の散布図を図6(b)に示す。図6(a)によるとI 軸は正の領域において “築 5 年以下”“空構成が 2 重以上”“隙間風を全く感じない”“断熱材あり”といったカテゴ リーが布置され，1軸はシェルター性能の優劣に対応していると思われる。一方，【軸で は注っきりした特徴仗示されていない。以上の結果㳔前回と同じ傾向を示している。次に， 図 6(b)を見ると，札幌が I 軸に扔いてほと儿ど正ひ領域に布置されている。カテゴリーの 散布図と対応させると，空構成が 2 重以上で断熱材を使用，築 5 年以下，隙間風を全く感じ ないという住戸が多く，シェル夕一性能が比較的良い領域に布置されている。また，青森， 盛岡などは，その他の都市と比べてI 軸の負の領域への広がりが小さいことがわかる。前 回の結果では，札幌以外の都市のばらつき㳉大きく地域的な差流見られなかったため，今 回の結果はシェルター性能がさらに向上していることを示すものといえる。

(2)暖房形態に関する因子を用いた分析 表3の9 16までけ因子を用いて分析を行った。 結果を図 7(a)，図 7(b)に示卞。図7(a)を見ると，室温，暖房時間，石油消費量ひ平均を含 むカテゴリーがI 軸が0付近，【軸仕正い領域に現れている。また，I 軸が正，【軸が負に なるほど，室温が高く，暖房時間が長く，石油消費量が多いというカテゴリーが見られる。 一方，I軸，【軸とも負の領域で忙逆になる。また，I 軸が正，【軸が負の領域には連続 的に住宅内を暖房できる“セントラルヒーティング”が，I 軸，I軸とも負の領域には間 欠的に部屋の一部を暖房することが主である“開放式ストーブ”が布置されている。

住戸の散布図を見ると次U 4 グループに区別できる。(1) I 軸の正の領域に布置され，分布 が右下がりになっているグループ(札幌, 青森)。これらの住宅では, 室温が高く, セント ラルヒーティングや煙突付ストーブを使用している。(2)上記(1)上似た形態を示しI 軸の正 の領域に比較的多く布置しているグループ(八戸，秋田，盛岡)。これらの地域で㳉，(1)に 比べるとばらつきが大きいものの，(1)に近い暖房形態の住户が見られる。(3) I 軸の負の領 
域に布置され，分布が左下がりになっているグループ(府中，いわき 。これらの住宅では室温が低く，暖房器具は開放型ストーブが中心と なる。(4)上記(3)と似た形態を示し I 軸の負の領域に比較的多く布置し ているグループ(宮古, 山形, 酒田, 福島, 会津若松, 仙台)。これら

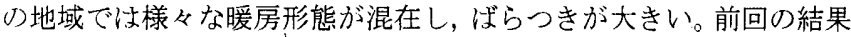
ではグループ(2)は見られず，グループ(1)，(3)，(4)に分類された。よっ て,今回の結果上り東北地方北部の住宅の暖房形態がグループ(1に近 づいていることが示される。

(3)居住性能に関する因子を用いた分析 表引に示す全ての因子を用 いて分析した結果を図8(a), 図8(b)に示す。暖房形態に関するカテゴ リーは図8(a)をI 軸に関して対象移動させたものと同じ傾向を示し， I 軸が正，II軸が正になるほど室温が高く，暖房時間が長く，石油消 費量が多いというカテゴリーが見られる。II 軸让シェルタ一性能を示 し，正の領域に性能ひ良いことを示寸゙カテゴリーが布置される。全体 的に，I軸，【軸ひ正の領域にシェルター性能が良好で室温が高いと いうカテゴリーが布置される。

住戸の散布図を見ると暖房形態の場合と同様に4グループに区別で きる。今回の結果では地域の差が前回上りも明確に見られるように なったといえる。また，青森が札幌ひ居住性能に近の゙いたことや東北 地方北部の都市の居住性能が札幌に近づいていること, 府中と東北地 方中・南部の都市との区別が明確に現れていることなどから，東北地 方の住宅の居住性能㳉程度ひ差はあるもりの前回と比べて向上してお り，札幌の居住性能に近ゔきつつあることがわかる。

\section{5. まとめ}

東北地方 12 都市及び札璂，府中の戸建住宅を対象としてアンケー 卜調査と居間及び寝室の室温調査を行い, 10 年前に行った同様ひ調査 ひ結果と比較した。その結果，以下ひことが明らかになった。

(1)東北地方都市部の住宅の居住性能は，10 年前と比べてさらに札

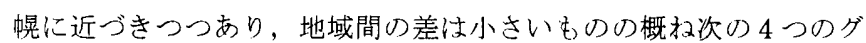
ループに類型化できた。i)居住性能が札幌に類似した，青森。ii)居住 性能が札幌に比較的近い，八戸，秋田，盛岡。iii)柇幌と汇対照的な 居住性能を示し，府中と同じグループと見なせる，いわき，iv)上記
表 3 数量化而類で用いた因子

\begin{tabular}{|c|c|c|c|c|}
\hline & No. & \multicolumn{3}{|c|}{ 因子及びカデゴリー数 } \\
\hline \multirow{8}{*}{$\begin{array}{c}\text { シェルター } \\
\text { 性能 }\end{array}$} & 1 & 築年数 & 5 & \multirow{8}{*}{$\begin{array}{c}\text { シェル } \\
\text { ター } \\
\text { 性能 }\end{array}$} \\
\hline & 2 & 床面積 & 5 & \\
\hline & 3 & 隙間風の感じ方 & 5 & \\
\hline & 4 & 断熱材の有無 & 2 & \\
\hline & 5 & 日照 & 2 & \\
\hline & 6 & 雨戸の有無 & 2 & \\
\hline & 7 & 居間の空構成 & 4 & \\
\hline & 8 & 居間の床構成 & 4 & \\
\hline \multirow{3}{*}{ 温熱環境 } & 9 & 居間朝室温 & 6 & \multirow{6}{*}{$\begin{array}{l}\text { 暖房 } \\
\text { 形態 }\end{array}$} \\
\hline & 10 & 居間昼空温 & 6 & \\
\hline & 11 & 居間夜室温 & 6 & \\
\hline $\begin{array}{l}\text { エ䄀”- } \\
\text { 消費量 }\end{array}$ & 12 & 石油消費量 & 7 & \\
\hline \multirow{2}{*}{ 設備 } & 13 & 主暖房器具 & 5 & \\
\hline & 14 & こたつの有無 & 2 & \\
\hline \multirow{4}{*}{ 住まい方 } & 15 & 暖房時間のタイフ & 6 & \\
\hline & 16 & 暖房期間 & 5 & $\gamma$ \\
\hline & 17 & 男性の着衣量 & 5 & 4 \\
\hline & 18 & 女性の着衣量 & 4 & 人間 \\
\hline 居住者特性 & 19 & 年間収入 & 5 & $\downarrow$ \\
\hline
\end{tabular}

ii), iii)ひ中間に位置し, 両者にまたがる, 宮古, 山形, 横手, 酒田, 福島, 会津若松, 仙台。これらの差異㤌室温と暖房形態によるところ が大きく, 傾向として, 東北地方の住宅の居住性能は，さらに札幌に 近づくものと予想される。

(2)断熱材の有無, 空や床構成などの住戸のシェルター性能につい て,10年前の結果では札幌とその他の都市とに二分され東北地方の中 での差注見られなかったが, 今回の結果では青森, 盛岡のシェルター 性能が札帽に近いことがすかった。

(3)液晶温度計により測定した居間温度の平均値は朝が最も低く 14 C，逆に夜が最も高く20 Cとなった。10年前の調查結果と比較する と室温汁全体的に上昇して扔り，特に朝の室温の上昇が大きい。しか し, 寝室温度は低く, 各都市に打ける居間と疫室の温度差の平均值は 札幌が最も小さく5Cであるが，秋田で忙 11 Cと最も大きい。

(4)数量化理論 I 類による分析の結果, 団ら儿時の室温のげらつきに 大きく寄与方名因子沬, 床面積, 暖房時間, 石油消費量, 着衣量, 年 間収入などであり，10 年前との結果に大きな違い汉見られない。ま た, 石油消費量つばらつきに関して洁, 暖房器具, 室温, 暖房期間,

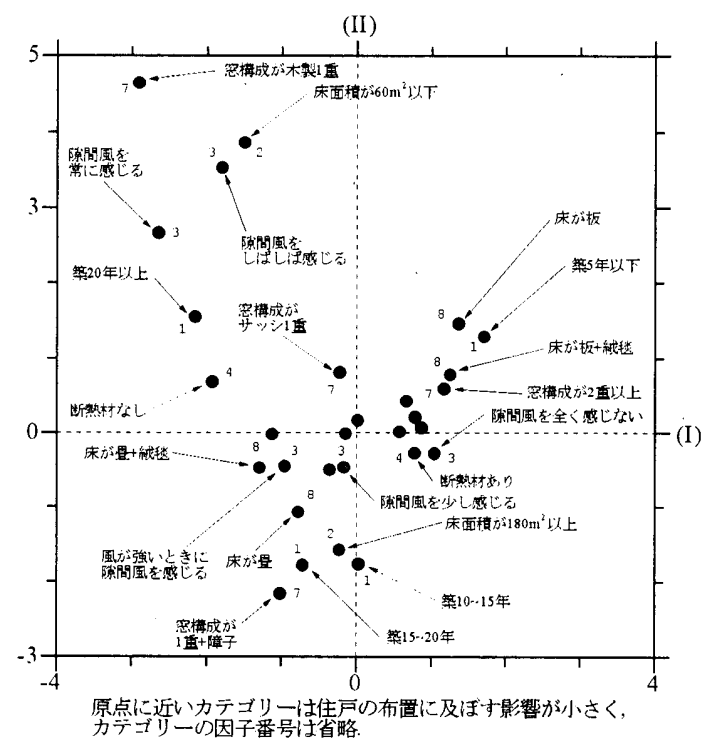

(a)カテゴリーの散布図(数字は因子の番号)

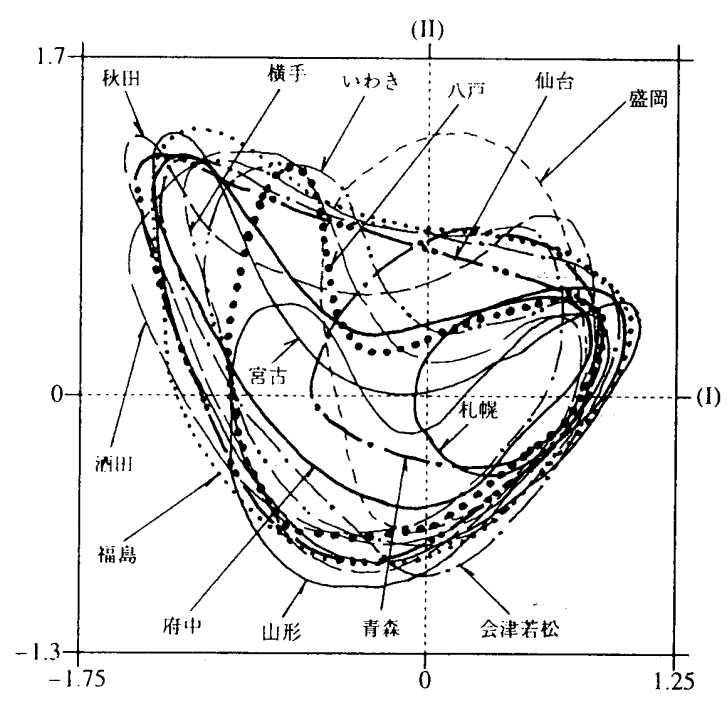

(b)住戸の散布図から得られた各都市の範囲

図 6 シェルター性能に関する数量化而類の分析結果 
(II)

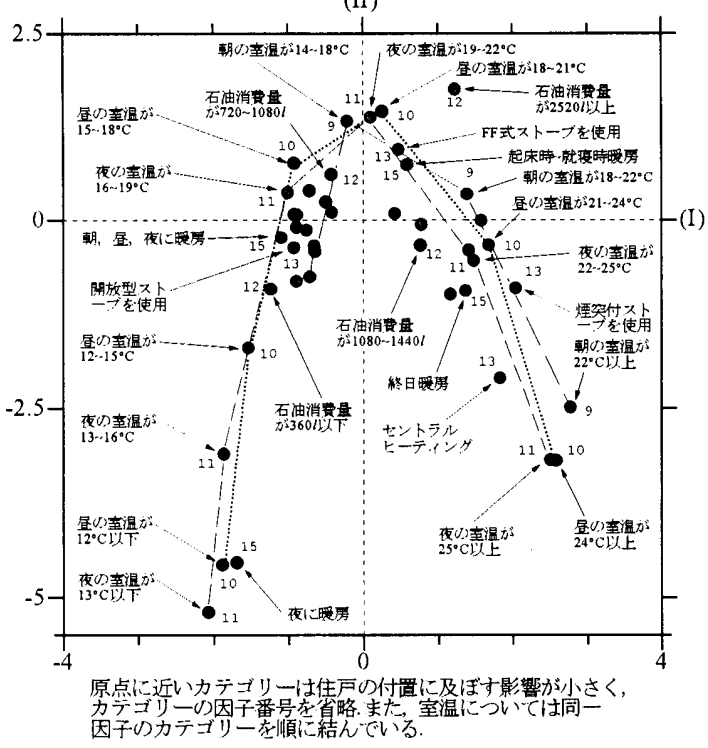

(a)カテゴリーの散布図(数字壮因子の番号)

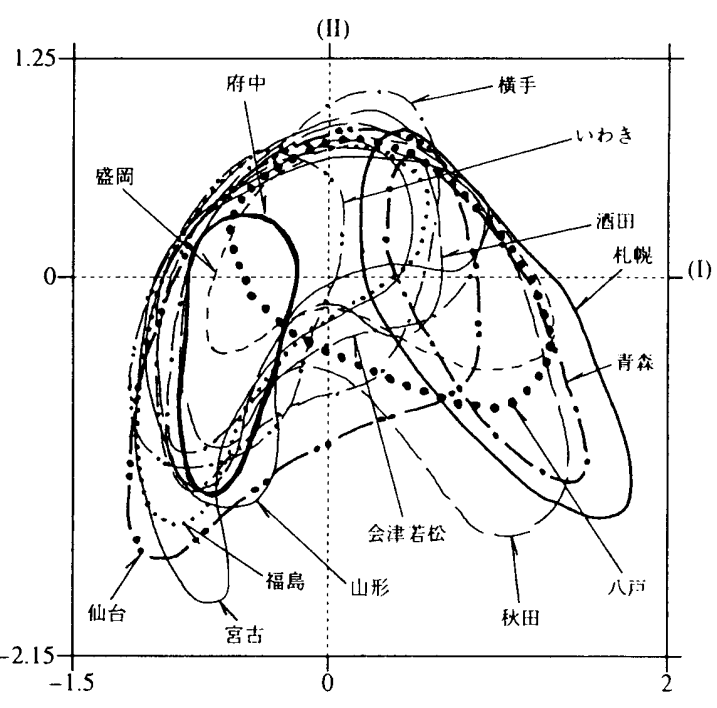

(b)住戸の散布図から得られた各都市の範囲

図 7 暖房形態に関する数量化而類の分析結果

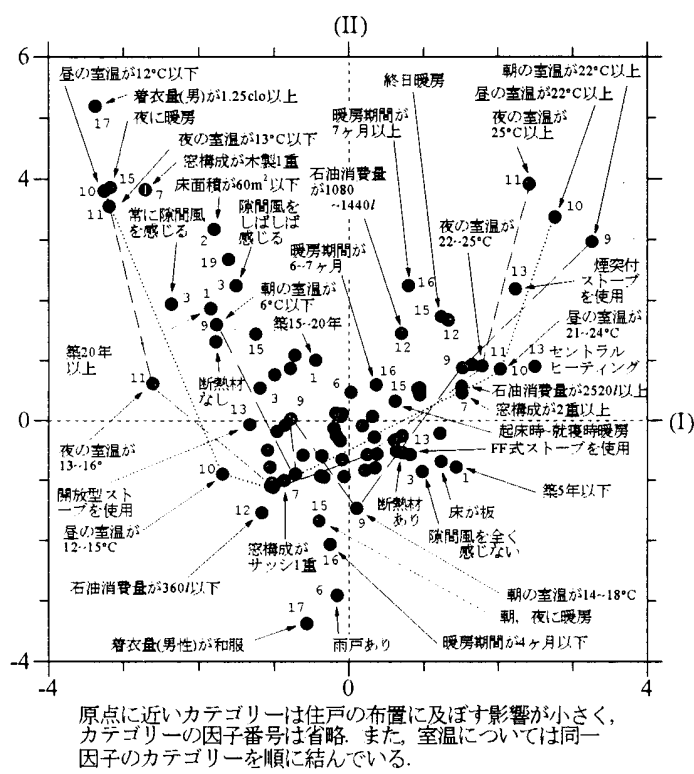

(a)カテゴリーの散布図(数字は因子の番号)

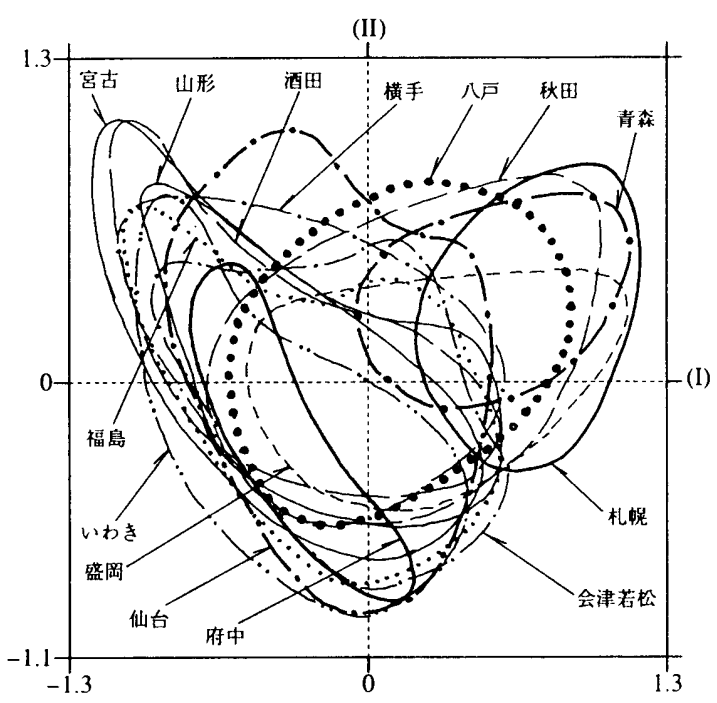

(b)住戸の散布図から得られた各都市の範囲

図 8 居住性能に関する数量化皿類の分析結果

石油暖房器具使用の部屋数, 年間収入などであり, 特に, 昼と夜の室 温が石油消費量に及注す影響が 10 年前よりも大きくなっている。し かし，これらの因子を考慮しても室温及び石油消費量の都市間の差は 大きい。札幌については, 外気温が低いことや暖房面積が広いことな どが影響していると考えられるが, 東北地方の都市間の差は, 10 年前 と同様に暖房度日や民力では十分に説明できなかった。

\section{あとがき}

本論文をまとめるに当たり, 当時東北大学学生・办谷篤氏の協力を得た。ま た，調查在行うに当たって，各都市の教育委員会，学校の関倸者の方々，調查 対象住戸の皆様にご協力頂いた。関係各位に謝意を表する次第である。

注

1) 例えば，新筑住宅の断熱材の使用率は 1982 年の $82 \%$ から 1991 年の $97 \%$ に上昇しているき。

2) 縦 $15 \mathrm{~cm}$ ，横 $22 \mathrm{~cm}$ ，厚さ $0.5 \mathrm{~cm}$ の断熱材に貼り付けたものであり，温度 計部分壮 10 年前に使用したものと同一である。測定範囲は $0 \sim 30^{\circ} \mathrm{C}$, 目盛

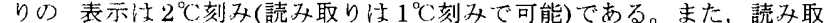
り精度は文献 1)に执いて検討した通り，測温抵抗体に上る測定值と $\pm 2^{\circ} \mathrm{C}$ の範囲で概ね一致して㧍り，地域的な差を把握することを目的とする本調
查にて用いるに壮問題ない中心上考之以孔る。

3) 壁, 床、天井、押入、ガラス,サッシなど、それれぞれの部位に扔ける結露 の有無についてけ質問を集計した結果である。

4) 石油用途について忙, 暖房け力, 暖房と風呂, 暖房と給湯などが考えられ, 暖房の为の使用は， 1982 年で $57 \% ， 1992$ 年で $44 \%$ であった。

5)「灯油のひと冬の使用量は例年どれくらいですか」といら質問に対する回 答をもとにしている。

6) 連続変数(目的変数)をいくつかのカデゴリーデータ(説明変数)で予測す るための手法。

7) 10 年前のデータでゆ重相関保数 0.64 , 奇与率 0.41 であった。

8) 10 年前のデータで收重相関保数 0.68 ，寄与率 0.47 であった。

9) カテゴリーに対する反応の仕方の似ているサンプルが近くなるように，一 方反応のされ方の似ているカテゴリーが近くなるようにサンプルとカテゴ リーを学れぞれ数量化する方法。

\section{参考文献}

1) 吉野 博, 長谷川房雄, 澤田紘次, 石川善美, 赤林伸一, 菊田道宣: 熱環 境から見た冬期の居住性能に関寸る地域特性ひ分析 一東北地方都市部を 対象として , 日本建築学会計画系論文報告集 第 345 号, pp.92 pp.103, 1984 年 11 月.

2) 小田原隆：高断熱高気密化の動向(1) 断熱材について, IBEC No.89, pp. $53 \sim$ pp. 56,1995 年 5 月

3) 民力 90 , 朝日新聞社, 1992 年 4 月.

1996年 9 月 10 日原稿受理， 1997 年 4 月 8 日採用決定 